\title{
Congresso Internacional de Ciências Administrativas
}

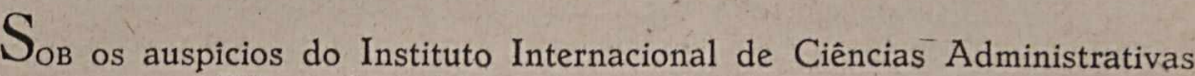
realizar-se-á em Wiesbaden, Alemanha, de 30 de agôsto a 3 de setembro p. vindouros, o XyI Congresso Internacional de Ciências Administrativas.

Como se sabe, o Instituto Internacional de Ciências Administrativas - da qual a Seçâo Brasileira é o Instituto Brasileiro de Ciências Administrativas -.. tem por objetivo a difusão, no plano internacional, dos principios gerais de administração pública, o exame comparativo das experiências realizadas nesse campo, o planejamento de métodos racionais de trabalho e os estudos, investigações, projetos e convênios que visem ao aperfeiçoamento das ciências e práticas administrativas.

O I. I. C. A. mantém contato com 64 países, quer seja por intermédio dos próprios Governos - que o integram como Estados-membros - quer seja pelo estabelecimento de Seções Nacionais (representantes locais do I.I.C.A.), ou, ainda, diretamente com membros individuais ou coletivos.

O próximo Congresso Internacional de Ciências Administrativas abordará os seguintes temas:

- A devolução de podêres a instituições autônomas, nelas compreendidos os organisinos profissionais e as universidades.

- A estrutura administrativa e as funções do Ministério da Fazenda (bem como do T'esouro e do Orçamento).

- O aumento de eficiência da Administração através da concessão de incentivos diversos aos funcionários.

- A automação e seus problemas na administração pública.

O 1. tema já foi objeto de um exame preliminar nas Mesas-Redondas de Opatija e Liège, realizadas em 1957 e 1958, respectivamente. Terá como Relator-Geral o Prof. Brian Chapman, da Universidade de Manchester.

Baseado nos elementos coligidos nas referidas Mesas-Redondas, e nas respostas ao questionário enviado aos diversos paises participantes, apresentará o Prof. CHAPMAN um relatório preliminar, compreendendo, principalmente:

- uma introdução terminológica, explicando as razões de adoção da expressão "devolução de podêres"; 
- um capítulo destinado a discussão das tendências gerais da matéria; autoridade.

- outro capitulo ao estudo da devolução dos podêres de gestão e de

O Instituto Brasileiro de Ciências Administrativas apresentará um relatório, elaborado pelo Prof. CAIO TÁcrto.

Após a discussão de Wiesbaden, será preparado e publicado o relatório final do Instituto Internacional.

O 2: tema - "Estrutura Administrativa do Ministério da Fazenda" será abordado pela primeira vez. Tem como relator o Sr. LAureano Lopez Rodó, da Espanha.

O estudo dêsse tópico tem por objetivo o confronto comparativo da organização e funcionamento dos serviços de finanças: orçamento, impostos e taxas, tesouraria, divida pública, contabilidade pública, dominio do Estado, etc.

O Instituto, Brasileiro de Ciências Administrativas convidou o Doutor Antônio Barçante dos Santos, Diretor da Divisão de Orçamento e Organizaçäo do D.A.S.P., para elaborar o relatório brasileiro. O convite foi aceito pelo Dr. BARÇAnTE.

O 3? tema - "O aumento da eficiência da Administração através da concessão de incentivos diversos aos funcionários" - também será focalizado, pela primeira vez, no Instituto Internacional de Ciências Administrativas. Serão examinados os prêmios e incentivos de tôda espécie, com exclusão das questões ligadas às relações humanas pròpriamente ditas.

O relator-geral será o Sr. Herbert Bursche, da República Federal da Alemanha. Planejou seu trabalho de modo a não se limitar a uma simples descrição dos métodos utilizados, mas a abranger tambẻm um retrospecto da evolução geral que os caracteriza nos diferentes países e apresentar, se possivel, uma conclusão geral sôbre sua utilização.

O Instituto Brasileiro de Ciências Administrativas encarregou sua Chefe de Pesquisas, Prof Beatriz Wahrlich, de elaborar o relatório brasileiro, que foi encaminhado ao Relator-Geral em fevereiro p. passado.

O 4 ? e último tema do Congresso - "A automação e seus problemas na Administração Pública" - já foi objeto de estudos em Opatija e Liège. Será relator o Prof. Lowell HATTERY, da "American University", Washington D.C., Estados Unidos.

As discussōes serão baseadas numa nota introdutória do Prof. $\mathrm{H}_{\text {ATTERY }}$ e versarão principalmente os seguintes pontos:

1. O papel do órgão administrativo central de automação no que se refere a tomada de iniciativas e a prestação de assessoria.

2. Pessoal especializado necessário ao tratamento automático de dados. O papel dos serviços administrativos na formaçäo dêsse pessoal.

3. Perspectivas do movimento de pessoal causado pela automação. Processos tendentes a evitar ou diminuir o desemprêgo. 
4. Vantagens e desvantagens, em comparação com os equipamentos prontos (em série), dos conjuntos eletrônicos concebidos para determinado fim. Possibilidades dos pequenos conjuntos menos custosos.

5. Efeitos do tratamento automático de dados sôbre a estrutura é os métodos administrativos.

6. Influência exercida pelo tratamento automático de dados sôbre as técnicas de direção, sobretudo sôbre a elaboração das decisões.

Paralelamente à discussão dos mencionados temas, realizar-se-ão, durante o XI Congresso Internacional de Ciências Adninistrativas, duas reuniões especiais: uma, de professôres de Direito Administrativo e de Administração Pública; outra, dos membros de Conselhos de Estado e de Tribunais de Contas.

A reunião dos professôres de Direito Administrativo e de Administração Pública terá como principal objetivo o exame das conclusões gerais do relatório sôbre "O ensino superior da administração pública", do Prof. ANDRÉ Molitor, da Universidade de Louvain.

A reunião dos membros de Conselhos de Estado terá por base uma conferência a cargo da Seção Nacional Alemã do I.I.C.A.

Como se verifica, é bastante promissor o programa do XI Congresso Internacional de Ciências Administrativas, sendo de prever rse que dêle resultem informações, contatos e conclusões que efetivamente venham a contribuir para o progresso da Administração. 